\title{
Obtaining tissues and organs for transplantation and coronavirus infections: a scoping review
}

\author{
Obtenção de tecidos e órgãos para transplante e infecções por coronavírus: revisão de escopo
}

Obtención de tejidos y órganos para trasplante e infecciones por coronavirus: revisión de alcance

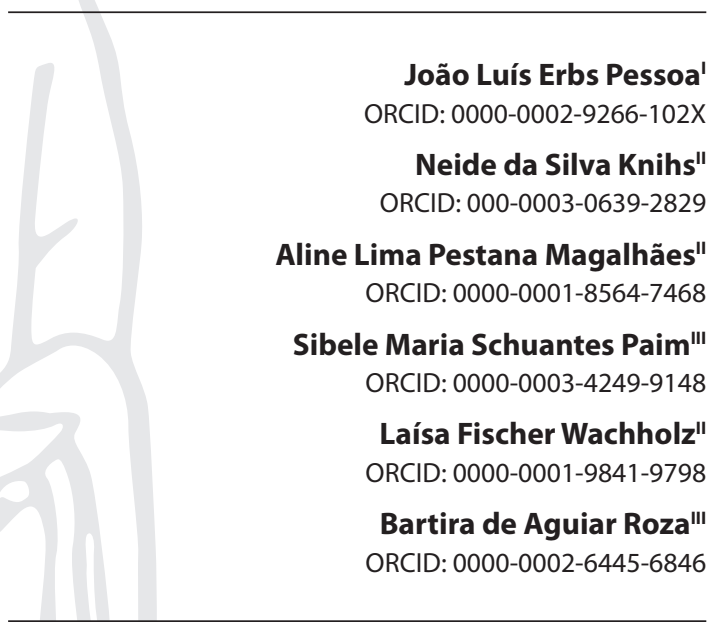

'Estado de São Paulo, Secretaria Estadual da Saúde. São Paulo, São Paulo, Brazil. "Universidade Federal de Santa Catarina. Florianópolis, Santa Catarina, Brazil. I'Universidade Federal de São Paulo. São Paulo, São Paulo, Brazil.

How to cite this article:

Pessoa JLE, Knihs NS, Magalhães ALP, Paim SMS, Wachholz LF, Roza BA. Obtaining tissues and organs for transplantation and coronavirus infections: a scoping review. Rev Bras Enferm. 2021;74(Suppl 1):e20200610. doi: http://dx.doi.org/10.1590/0034-7167-2020-0610

\section{Corresponding author: \\ João Luís Erbs Pessoa \\ E-mail: joaoerbs@gmail.com}

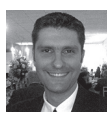

EDITOR IN CHIEF: Dulce Barbosa ASSOCIATE EDITOR: Marcia Magro

Approval: 12-21-2020

\section{ABSTRACT}

Objective: to map the care recommendations available in the literature capable of supporting health professionals' decision-making in the organ and tissue donation process before the COVID-19 pandemic. Methods: is a nine-step scoping review with searches performed in three databases and an electronic library (Science Direct). Results: 873 publications were retrieved, 15 selected for analysis. All were published in 2020, originating mainly on China, with predominance of original articles. The most frequent recommendations relate to testing to detect SARS-CoV-2 infection for deceased donors (52.6\%) and clinical evaluation of potential donors and possible donors (31.6\%). Final considerations: it is believed that the recommendations evidenced will support health professionals in the process of donation and organ transplantations to determine interventions for decision-making during the COVID-19 pandemic.

Descriptors: Coronavirus Infections; Pandemics; Tissue and Organ Procurement; Organ Transplantation; Donor Selection.

\section{RESUMO}

Objetivo: mapear as recomendações de cuidados disponíveis na literatura capazes de subsidiar a tomada de decisão de profissionais da saúde atuantes no processo de doação de órgãos e tecidos diante da pandemia de COVID-19. Métodos: trata-se de uma revisão de escopo desenvolvida em nove etapas com buscas realizadas em três bases de dados e uma biblioteca eletrônica (Science Direct). Resultados: foram recuperadas 873 publicações, 15 selecionadas para análise. Todas foram publicadas em 2020, tendo como origem principalmente a China, predominando artigos originais. As recomendações mais frequentes se relacionam com a realização de testes para detectar a infecção por SARS-CoV- 2 para doadores falecidos $(52,6 \%)$ e avaliação clínica do potencial doador e possível doador $(31,6 \%)$. Considerações finais: acredita-se que as recomendações evidenciadas subsidiarão os profissionais de saúde atuantes no processo de doação e transplantes de órgãos a determinar intervenções para a tomada de decisão durante a pandemia de COVID-19.

Descritores: Infecções por Coronavírus; Pandemias; Obtenção de Tecidos e Órgãos; Transplante de Órgãos; Seleção do Doador.

\section{RESUMEN}

Objetivo: mapear las recomendaciones de atención disponibles en la literatura capaces de apoyar la toma de decisiones de los profesionales de la salud que trabajan en el proceso de donación de órganos y tejidos ante la pandemia de COVID-19. Métodos: es una revisión de alcance desarrollada en nueve etapas con búsquedas realizadas en tres bases de datos y una biblioteca electrónica (Science Direct). Resultados: se recuperaron 873 publicaciones, 15 seleccionadas para su análisis. Todos fueron publicados en 2020, originados principalmente en China, con predominio de artículos originales. Las recomendaciones más frecuentes están relacionadas con las pruebas para detectar la infección por SARS-CoV-2 en donantes fallecidos $(52,6 \%$ y la evaluación clínica del donante potencial y posible donante $(31,6 \%)$. Consideraciones finales: se cree que las recomendaciones evidenciadas subsidiarán a los profesionales de la salud que trabajan en el proceso de donación y trasplante de órganos para determinar intervenciones para la toma de decisiones durante la pandemia de COVID-19. Descriptores: Infecciones por Coronavirus; Pandemias; Obtención de Tejidos y Órganos; Trasplante de Órganos; Selección de Donante. 


\section{INTRODUCTION}

Coronavirus of severe acute respiratory syndrome 2 (SARSCoV-2) is a highly contagious new virus that causes the disease called COVID-19, spreading rapidly through transmission between humans ${ }^{(1)}$. Transmission occurs through droplets and aerosols that are dispersed during speech, coughing, sneezing, use of musical wind instruments or health procedures. It is discussed the transmission through contact with contaminated surfaces following to sensitive regions such as eyes, mouth or nose $\mathrm{e}^{(2)}$.

The world is haunted by the COVID-19 pandemic. Since the first confirmed case in Brazil on February 26, 2020, the country has been on general alert, especially health professionals working on the front line to try to contain this disease $\mathrm{e}^{(3-4)}$. This situation was aggravated when, in March of the same year, the World Health Organization (WHO) defined that SARS-CoV-2 was a pandemic, i.e., that the virus was already present in several regions worldwide $\mathrm{e}^{(5-6)}$.

Just as all health areas needed adjustments to face this reality, professionals working in the organ and tissue donation process for transplantation purposes needed to seek information that could support decision-making related to donation in Brazil and worldwide, since a multi-organ donor can benefit many people. Thus, a contaminated donor may spread the virus to many recipients. Faced with this situation, the scientific community and professionals with expertise in donation and transplantation are establishing protocols and guides to guide this process. The risk of developing COVID-19 from an organ donor infected with the SARS-CoV-2 virus is unknown. Therefore, it is important to be careful when considering transplantation. Transmission is affected by epidemiological risk factors, incubation period, degree of viremia and viability of SARS-CoV-2 in blood and organs ${ }^{(7)}$.

The creation of protocols and flowchart establishments to guide the teams of Organ Procurement Organizations (OPO), as well as the IntraHospital Commissions for Organ and Tissue Donation for Transplantation (CIHDOTT - Comissões IntraHospitalares de Doação de Órgãos e Tecidos para Transplante) in the face of this pandemic scenario, has become something relevant for donation maintenance, or an attempt to validate a potential donor with minimal safety for health professionals and potential recipients.

Faced with a pandemic situation, the Brazilian National Transplant System made available the first technical note based on the gold recommendations defined by the WHO, suggesting some changes in the daily routine of OPO and CIHDOTT teams, which involve: developing active searches for patients in brain death by means other than face-to-face, such as e-mail, telephone, WhatsApp', among other possible forms of communication; adopt individual protection measures in each case of potential donor and conduct family interviews through specific care (give preference to meet in ventilated places, if possible limit the number of participants, provide alcohol in gel, make available place for hand hygiene, make available tissue scarves and use disposable cups) ${ }^{(8)}$.

These adjustments in the donation process provided support to the teams that are on the front line. However, with the exponential growth of confirmed diagnoses in Brazil, reaching $6,071,401$ cases and more than 169,183 deaths as of November 23 , the impact of this pandemic on organ transplants ${ }^{(4)}$ was observed. New doubts, concerns, fear and insecurity arise daily to the teams working in OPOs and CIHDOTTs on how to validate a potential organ and tissue donor in the face of this pandemic.

It is noteworthy that one of the premises in the donation process, performed by the teams of OPOs and CIHDOTTs, is the clinical evaluation of potential donors to ensure the lowest risk of transmission of diseases to recipients. This evaluation performed through physical, laboratory and imaging examination is protected by laws, decrees and resolutions. However, the transplant team also participates in this process, mainly in the evaluation of relative contraindications, pursuant to Decree 9,175 of October $18,2017^{(9)}$. Due to this reality, the Brazilian National Transplant System has already observed a decrease in some modalities of transplants in the first quarter of 2020 compared to 2019, such as a $22 \%$ decrease in heart transplants, $18 \%$ in lung transplants and the interruption of corneal transplants that do not meet the prioritization criteria(10).

The Ministry of Health issued Technical Note 34/2020(11) regarding the criteria for the screening of candidates for organ and tissue donation for the management of patients on the waiting list before the current pandemic. Through these recommendations, it aims to protect health professionals and patients from contamination by COVID-19 so that the active search and uptake of organs and tissues is carried out safely and with quality.

The clinical screening of potential donors has become an essential tool evidenced in several studies ${ }^{(12-15)}$. In Brazil, carrying out the molecular biology test to detect viral RNA has also become a necessity for the continuity of solid organ transplants. However, especially in the first weeks after the decreed community transmission of COVID-19, there was a limitation in the availability of tests ${ }^{(16-17)}$. In our daily practice with the organ and tissue donation process, at the beginning of the pandemic, there were moments of scarcity of kits to test all potential donors.

The inequality of resources that occurs due to the regional differences in Brazil and internal logistics problems generates problems to obtain the results of tests for the detection of coronavirus in potential donors, since, in some regions, they are released within 24 hours after collection; and in others, within 48 hours after collection, which may impact its hemodynamic maintenance and increased risk of infection of potential donors by the virus. The experience in China shows that this time can be reduced to up to six hours, making this screening stage more efficient ${ }^{(18)}$.

Many difficulties and uncertainties are being faced during the pandemic before the rapid spread of the disease, directly impacting the activity of donation and transplantation, such as: professionals who can become contaminated and be vectors of the disease; lack of beds for patients already diagnosed with brain death or for potential recipients; insecurity in performing transplantation during the pandemic; challenges of continuing post-transplant care ${ }^{(13,19)}$.

The study aims to identify recommendations that can support professionals in the pandemic scenario by COVID-19, especially nursing professionals working on the front line in both opo and CIHDOTT. Thus, it is essential and prudent that these professionals have up-to-date information to support decision-making in the conduct of each stage of organ and tissue donation. 
In view of this scenario, the fundamental question of this study was: what care recommendations are available in the scientific literature to support good practices in health professionals' decision-making who conduct the stages of organ and tissue donation process before the COVID-19 pandemic?

\section{OBJECTIVE}

To map the care recommendations available in the literature capable of supporting health professionals' decision-making in the organ and tissue donation process before the COVID-19 pandemic.

\section{METHOD}

\section{Ethical aspects}

As this is a literature review, the ethical criteria of authorship, referencing and copyright were respected.

\section{Study design, period, and location}

This is a scoping review supported by the method proposed by Joana Briggs Institute Reviewers ${ }^{(20)}$. This method consists of the following steps: (1) defining and aligning objectives and questions; (2) developing and aligning inclusion criteria with the objectives and question of the review; (3) describing the planned approach to search for evidence, selection, data extraction and presentation of evidence; (4) searching for evidence; (5) selecting the evidence; (6) extracting the evidence; (7) analyzing the evidence; (8) presenting the results; (9) summarizing the evidence regarding the objective of the review, concluding and observing any implications of results. The study was developed by researchers from the state of São Paulo and Santa Catarina. The collection of information, as well as the search in the databases, occurred in May 2020.

\section{Study protocol and analysis of results}

For the conduction of this study, according to the scoping review protocol, which will be available upon request to the main author, the following steps were followed: the first step was the definition and alignment of the objectives and the question of the review; PCC strategy construction (Population, Concept and Context)was followed, in which " $P$ " means population-patients with suspicion/confirmation of COVID-19; "C" means care for organ and tissue donation; " $\mathrm{C}$ " means the context of organ donation.

Thus, the fundamental question was defined: what care recommendations are available in the scientific literature to support health professionals' decision-making who conduct the stages of organ and tissue donation process before the COVID-19 pandemic?

In the second stage, development and alignment of inclusion criteria with the objectives and question of the review, original articles, experience reports, reflection articles, editorialarticles, guidelines, guidelines and guidelines in English, Brazilian Portuguese and Spanish published in 2020 were included that addressed the theme of organ and tissue donation in adult patients in the scenario of the COVID-19 pandemic. Exclusion criteria referred to review articles, since the researchers chose to search for information in primary studies in order to fully know all the findings.

The third stage, defined as a description of the planned approach for searching for evidence, selection, data extraction and presentation of evidence, considered the following databases: Medical Litetarure Analysis and Retrieval System Online (MEDLINE), consulted through PubMed, SCOPUS, Web of Science, and the following electronic library: Science Direct. These bases were chosen due to the fact that they are responsible for the wide dissemination of scientific materials produced on COVID-19. The following descriptors were defined: 2019-nCoV; COVID-19; coronavirus; SARS-CoV-2; transplantation; donor organ evaluation. It is noteable that, in each database, search strategies were constructed with the descriptors, keywords and Boolean operators, such as (COVID-19) AND (transplantation); (coronavirus) AND (COVID-19) AND (2019-nCoV) AND (transplantation). The defined time frame was from January to May 2020. This stage was performed independently, in which each reviewer developed the search in the databases in May.

In the fourth stage, search for evidence, after identifying the studies (873), the bibliographic manager Mendeley", in which the duplicate articles (six) were excluded, remaining 867 studies, which were submitted to the evaluation of titles and abstracts. 845 manuscripts were excluded, 833 because they were not related to the theme of organ and tissue donation and covid-19 pandemic and 12 because they were not primary studies. There was no exclusion of articles due to language. All studies were identified in Brazilian Portuguese, English, or Spanish. This stage was developed manually, although there is an expressive number of studies.

During the development of the fifth stage, selection of evidence, 22 studies remained, which were read in full; of these, 15 were selected to collect the information, and seven of the studies were excluded from this stage because it was not clear the eligibility criteria regarding the population and because they were not related to the theme of organ and tissue donation in the COVID-19 pandemic. In all stages, the differences between the reviewers were discussed and reviewed with the support of a third reviewer, who has expertise in organ and tissue donation for more than 20 years. To better understand the selection of the obtained material, a flowchart adapted from PRISMA-SCR ${ }^{(21)}$ was used.

In the sixth stage, extraction of evidence, a spreadsheet was created containing: title, author, journal, country, objective, methodological design, type of participant, concept, context/ recommendations and main evidence. At this stage, the reviewers searched for the information mentioned in the independently selected studies. After information collection, there was a meeting between the three reviewers to consensus the information obtained. This information comprised analysis of results according to the seventh stage, analysis of the evidence.

The eighth stage, known as presentation of results, refers to separation, sumarization, data integration and results reporting. After data collection, the information obtained was read and analyzed, at this moment, by all researchers through two virtual meetings. The findings/evidences that would be presented in the form of a picture were defined, pointing out the most relevant 
evidence/recommendations that were capable of supporting multidisciplinary team's decision-making in the process of organ and tissue donation before the COVID-19 pandemic. Finally, the ninth stage comprises the summary of evidence in relation to the objective of the review, drawing conclusions and observing any implications of results, presented in the results session.

\section{RESULTS}

The data collection included 15 original articles, all published in 2020 , with the origin of China $(n=05,35.71 \%)$, the United States ( $n=04,28.57 \%)$, Italy ( $n=03,21.42 \%)$, a study in the Netherlands, one in Canada and one in Spain. Regarding the type of study, we identified $(n=07,46.6 \%)$ expert opinion studies, $(n=06,40.0 \%)$ exploratory and descriptive and ( $n=02,13.33 \%$ ) experience reports. Regarding the database, the largest number of manuscripts was identified in Science Direct ( $n=06,40.0 \%$ ), followed by SCOPUS ( $n=04,26.6 \%$ ).

Figure 1 below presents the development of the selection of the original manuscripts as well as the reasons for exclusion.

A chart will be presented below with information obtained from the original manuscripts. The type of study, the country in which it was developed and the main recommendations to support team's decision-making in the stages of organ and tissue donation for transplantation before the COVID-19 pandemic will be presented.

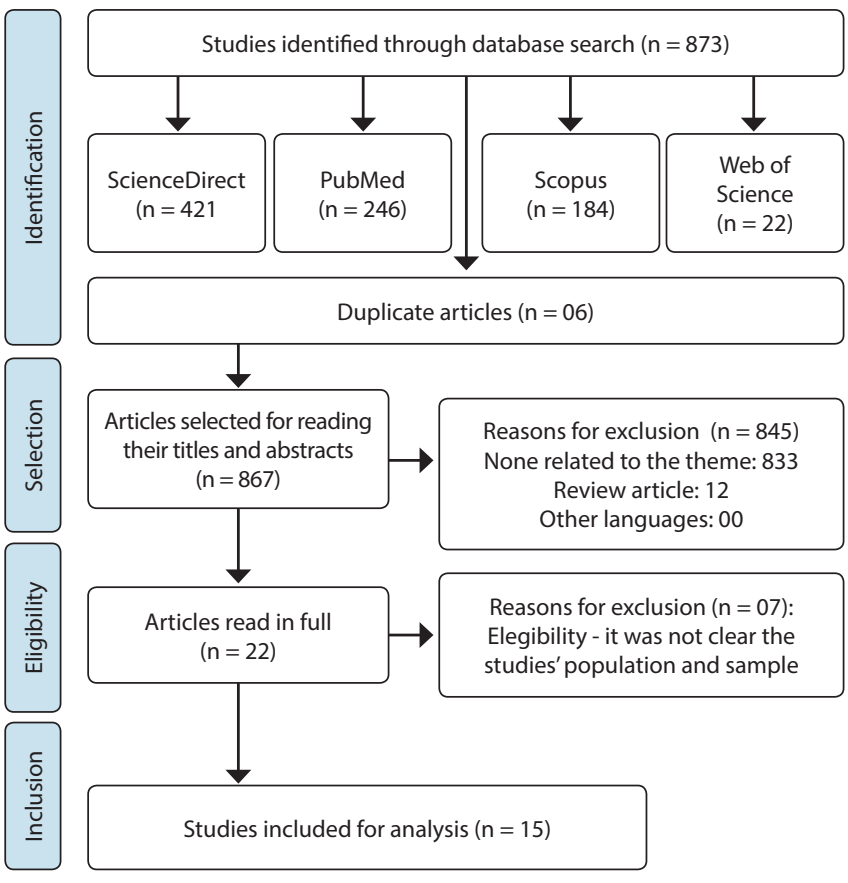

Figure 1 - PRISMA-SCR flowchart ${ }^{(21)}$
Chart 1 shows the main care recommendations for good practices in organ donation obtained through the original manuscripts.

With regard to the main recommendations identified, testing for detecting COVID-19 for all deceased donors presented a frequency of $52.6 \%$, i.e., it appeared ten times as a recommendation in the articles found ${ }^{(12,14,15,22-24,26-27)}$. In two of them, there was an indication to collect endotracheal material, instead of a cotton swab, to increase the sensitivity of the test to the virus ${ }^{(7,22)}$.

As for the absolute and relative contraindications, there was a divergence between the guidelines between the publications evaluated. One of the articles points out that, in the case of cured patients, one must wait 21 days from the cure for donation to occur ${ }^{(23)}$; donation should be declined in asymptomatic individuals who have been in an area affected by COVID-19 in the past 28 days $^{(7)}$; for potential donors with a clinical standard compatible with COVID-19, donation should be excluded ${ }^{(7,23)}$; potential donors who do not show compatible symptoms, but are suspected, should perform the test for virus detection and discard the donation if the result is positive ${ }^{(23)}$. A study points out that only negative COVID-19 donors are considered for organ donation $^{(14)}$. Another study points out that asymptomatic individuals monitored after contact with a proven case of COVID-19 should be excluded from the donation. It is also recommended not to donate lungs or small intestines. Low-risk or negative test donors, as well as those who have recovered from COVID-19 (more than 28 days), are likely to be safe to use $\mathrm{e}^{(7)}$.

Regarding the performance of $\mathrm{CT}$, two studies scored this image as a recommendation in the case of patients with a previous history and negative nasopharyngeal swab ${ }^{(22,26)}$. Regarding the recommendations regarding signs and symptoms, they represent $31.6 \%$ of the recommendations, being observed in six articles found. Attention was given to vesicular lesions, itching, herpes and skin lesions ${ }^{(28)}$. Clinical symptoms, such as fever, dyspnea, dry cough, recent diarrhea, as well as signs of bilateral frosted glass or irregular opacity on radiological examinations, lymphopenia and eosinopenia, loss of smell and gastrointestinal symptoms, were considered $^{(1,29-31)}$.

Regarding the continuity in carrying out transplants, two articles point out that transplants should be performed with caution in times of pandemic, evaluating risk and benefit ${ }^{(22,24)}$. Another three consider that if a transplantation is performed with extreme urgency, it is necessary to properly exclude SARSCoV-2 infection in both donors and recipients (mandatory) ${ }^{(7,14-15,25)}$.

Regarding recommendations to the health team, two studies point out the risk of contamination during donors' hospitalization period ${ }^{(24,26)}$. Another study points out the care regarding the risk of the team contaminating potential donors ${ }^{(12)}$. Moreover, all donor staff must have training for COVID-19(12,15).

Chart 1 - Characterization of studies included in the scoping review. Country, year, design, objective and evidence

\begin{tabular}{|l|c|l|l|l|}
\hline Title & $\begin{array}{c}\text { Year } \\
\text { Country }\end{array}$ & Design & Objective & Evidence \\
\hline $\begin{array}{l}\text { Clinical features of } \\
\text { patients infected } \\
\begin{array}{l}\text { with } 2019 \text { novel } \\
\text { coronavirus in } \\
\text { Wuhan, China }\end{array}\end{array}$ & $\begin{array}{l}2020 \\
\text { China }\end{array}$ & $\begin{array}{l}\text { Exploratory } \\
\text { study }\end{array}$ & $\begin{array}{l}\text { To report epidemiological, } \\
\text { clinical, laboratory and } \\
\text { radiological characteristics, } \\
\text { treatment and clinical outcomes } \\
\text { of these patients. }\end{array}$ & $\begin{array}{l}\text { Pay attention to computed tomography (CT) of the chest } \\
\text { with abnormal findings and acute respiratory distress } \\
\text { myalgia, or fatigue. Note for less common symptoms: } \text { sputum } \\
\text { production, headache, dyspnea, and lymphopenia. }\end{array}$ \\
\hline
\end{tabular}




\begin{tabular}{|c|c|c|c|c|}
\hline Title & $\begin{array}{c}\text { Year } \\
\text { Country }\end{array}$ & Design & Objective & Evidence \\
\hline $\begin{array}{l}\text { Organ donation } \\
\text { during the } \\
\text { coronavirus } \\
\text { pandemic: an } \\
\text { evolving saga in } \\
\text { uncharted waters } \\
\text { un }\end{array}$ & $\begin{array}{l}2020 \\
\text { USA }\end{array}$ & $\begin{array}{l}\text { Expert } \\
\text { opinion } \\
\text { study }\end{array}$ & $\begin{array}{l}\text { To discuss care when } \\
\text { considering transplantation, } \\
\text { considering that coronavirus } \\
\text { transmission is affected by } \\
\text { epidemiological risk factors, } \\
\text { incubation period, degree of } \\
\text { viremia and viability of SARS } \\
\text { - CoV - } 2 \text { in blood and organ } \\
\text { compartment. }\end{array}$ & $\begin{array}{l}\text { Perform C-reactive protein (CRP) } 24 \text { hours before donation } \\
\text { in dead and living donors. Discard the donation of those } \\
\text { who are positive for COVID-19. It is suggested to perform } \\
\text { bronchoalveolar lavage as it is more sensitive in potential } \\
\text { donors. Be extremely careful when considering the need } \\
\text { for a transplant and accepting donors. Donation must be } \\
\text { declined in asymptomatic individuals who have been in an } \\
\text { area affected by COVID-19 in the past } 28 \text { days. Asymptomatic } \\
\text { individuals monitored after contact with a proven case of } \\
\text { COVID-19 are excluded from the donation. Transplants from } \\
\text { non-urgent deceased donors and living donors should be } \\
\text { suspended. There should be no donation of lungs or small } \\
\text { intestine. Low-risk or negative donors for the test, as well } \\
\text { as those who have recovered from COVID-19 (more than } 28 \\
\text { days), are likely to be considered safe for donation. }\end{array}$ \\
\hline $\begin{array}{l}\text { Challenges and } \\
\text { countermeasures } \\
\text { for organ donation } \\
\text { during the SARS- } \\
\text { CoV-2 epidemic: } \\
\text { the experience of } \\
\text { Sichuan Provincial } \\
\text { People's Hospital(12) }\end{array}$ & $\begin{array}{c}2020 \\
\text { China }\end{array}$ & $\begin{array}{l}\text { Experience } \\
\text { report }\end{array}$ & $\begin{array}{l}\text { To report the donation protocol } \\
\text { of the Sichuan Province People's } \\
\text { Hospital }\end{array}$ & $\begin{array}{l}\text { Laboratory test according to the SARS-CoV-2 and chest } \\
\text { CT guidelines before donation. Conduct epidemiological } \\
\text { screening for potential donors and their families (travel } \\
\text { history and suspected respiratory infections). Evaluate clinical } \\
\text { symptoms such as fever, dyspnea, dry cough, diarrhea. } \\
\text { During donor maintenance in the ICU, patients should not } \\
\text { have contact with patients infected with COVID-19, nor } \\
\text { should the team have a history of contact with these patients. } \\
\text { The entire team involved in the donation process must have } \\
\text { participated in training on epidemiological knowledge } \\
\text { related to COVID-19. The team must have been trained in } \\
\text { the epidemic situation of the hospital from which donors } \\
\text { originate and decide whether to accept donors or not. }\end{array}$ \\
\hline $\begin{array}{l}\text { The COVID-19 } \\
\text { outbreak in Italy: } \\
\text { Initial implications } \\
\text { for organ } \\
\text { transplantation } \\
\text { programs }^{(14)}\end{array}$ & $\begin{array}{l}2020 \\
\text { Italy }\end{array}$ & $\begin{array}{l}\text { Expert } \\
\text { opinion } \\
\text { study }\end{array}$ & $\begin{array}{l}\text { To discuss the implications for } \\
\text { organ transplantation activity } \\
\text { considering the spread of } \\
\text { COVID-19. }\end{array}$ & $\begin{array}{l}\text { Perform PCR } 24 \text { hours before donation in dead and living } \\
\text { donors. All possible donors should be screened for SARS- } \\
\text { CoV-2 using PCR with samples of nasopharyngeal swabs } \\
\text { or bronchoalveolar lavage fluids. Only donors without } \\
\text { COVID-19 are considered for organ donation. In the case of } \\
\text { transplantation with extreme urgency, exclude infection by } \\
\text { COVID-19 in both donors and recipients. }\end{array}$ \\
\hline $\begin{array}{l}\text { COVID-19: A } \\
\text { global transplant } \\
\text { perspective on } \\
\text { successfully } \\
\text { navigating a } \\
\text { pandemic }^{(15)}\end{array}$ & $\begin{array}{c}2020 \\
\text { Canadá }\end{array}$ & $\begin{array}{l}\text { Expert } \\
\text { opinion } \\
\text { study }\end{array}$ & $\begin{array}{l}\text { To discuss mitigation strategies, } \\
\text { such as donor screening, } \\
\text { resource planning, and a step- } \\
\text { by-step approach to transplant } \\
\text { volume considerations as local } \\
\text { resource issues require. }\end{array}$ & $\begin{array}{l}\text { Pay attention to the false negative rates of the tests, which } \\
\text { may be due to inadequate collection or incubation period. } \\
\text { Living and deceased donors should be tested for SARS- } \\
\text { CoV-2. Before deciding to perform the transplant, consider: } \\
\text { (1) introducing immunosuppression in patients in the middle } \\
\text { of a pandemic; (2) the risk versus benefit ratio of postponing } \\
\text { the transplant; (3) the rationing of health resources, } \\
\text { including hospital and outpatient resources. In cases of liver } \\
\text { transplantation, patients can be stratified based on the MELD } \\
\text { score and the decision to transplant only patients with high } \\
\text { MELD. Always evaluate priority level. }\end{array}$ \\
\hline $\begin{array}{l}\text { Immediate impact } \\
\text { of COVID-19 } \\
\text { on transplant } \\
\text { activity in the } \\
\text { Netherlands }{ }^{(22)}\end{array}$ & $\begin{array}{c}2020 \\
\text { Holanda }\end{array}$ & $\begin{array}{l}\text { Expert } \\
\text { opinion } \\
\text { study }\end{array}$ & $\begin{array}{l}\text { To detail the response of the } \\
\text { Dutch transplant community to } \\
\text { COVID- } 19 \text { and the immediate } \\
\text { consequences for transplant } \\
\text { activity. }\end{array}$ & $\begin{array}{l}\text { Implement the SARS-CoV-2 test for all deceased donors. It } \\
\text { is suggested that the SARS-CoV-2 test be performed with } \\
\text { endotracheal sputum. Perform CT in case of patients with } \\
\text { a previous history and negative nasopharyngeal swab. } \\
\text { Consider carrying out each transplant with caution. In liver } \\
\text { transplantation, focus on patients with high urgency and } \\
\text { those with Final Phase Liver Disease (MELD)> } 20 \text {. }\end{array}$ \\
\hline $\begin{array}{l}\text { Dramatic impact } \\
\text { of the COVID-19 } \\
\text { outbreak on } \\
\text { donation and } \\
\text { transplantation } \\
\text { activities in Spain }\end{array}$ & $\begin{array}{l}2020 \\
\text { Spain }\end{array}$ & $\begin{array}{l}\text { Expert } \\
\text { opinion } \\
\text { study }\end{array}$ & $\begin{array}{l}\text { To elucidate the } \\
\text { recommendations issued by } \\
\text { the Spanish system for the } \\
\text { evaluation and selection of } \\
\text { organ donors with respect to } \\
\text { SARS-CoV-2 infection and report } \\
\text { the impact of the COVID-19 } \\
\text { epidemic on the donation and } \\
\text { transplantation activity in Spain. }\end{array}$ & $\begin{array}{l}\text { Potential donor must perform PCR exam } 24 \text { hours prior } \\
\text { to extraction. In case of cured patients, wait } 21 \text { days after } \\
\text { the cure for the donation to occur. In case of exposure to a } \\
\text { confirmed case of COVID-19, wait } 21 \text { days. Potential donor } \\
\text { with clinical standard compatible with COVID-19, exclude } \\
\text { donation. Potential donor who does not show compatible } \\
\text { symptoms, but there is suspicion, perform the test for SARS- } \\
\text { CoV-2 and discard the donation if positive. }\end{array}$ \\
\hline $\begin{array}{l}\text { Coronavirus } \\
\text { disease } 2019 \text { and } \\
\text { transplantation: } \\
\text { A view from the } \\
\text { inside }\end{array}$ & $\begin{array}{l}2020 \\
\text { Italy }\end{array}$ & $\begin{array}{l}\text { Expert } \\
\text { opinion } \\
\text { study }\end{array}$ & $\begin{array}{l}\text { To elucidate the guidelines } \\
\text { published by the Italian } \\
\text { Transplantation Authority on } \\
\text { donor management, as well } \\
\text { as describe the preventive } \\
\text { measures implemented by a } \\
\text { transplant center in Milan. }\end{array}$ & $\begin{array}{l}\text { Perform PCR exam with nasopharyngeal swab (SPL) or } \\
\text { bronchoalveolar lavage and exclude positive donors. } \\
\text { Carefully evaluate the costs and benefits of performing a } \\
\text { transplant during the COVID-19 outbreak. Patient can be } \\
\text { infected after hospitalization by health professionals and } \\
\text { other close contacts. Thus, there is a need for great caution to } \\
\text { accept donors. }\end{array}$ \\
\hline
\end{tabular}




\begin{tabular}{|c|c|c|c|c|}
\hline Title & $\begin{array}{c}\text { Year } \\
\text { Country }\end{array}$ & Design & Objective & Evidence \\
\hline $\begin{array}{l}\text { Coronavirus } \\
\text { disease } 2019 \text { : } \\
\text { Utilizing an ethical } \\
\text { framework for } \\
\text { rationing absolutely } \\
\text { scarce health- } \\
\text { care resources } \\
\text { in transplant } \\
\text { allocation } \\
\text { decisions }^{(25)}\end{array}$ & $\begin{array}{l}2020 \\
\text { USA }\end{array}$ & $\begin{array}{l}\text { Expert } \\
\text { opinion } \\
\text { study }\end{array}$ & $\begin{array}{l}\text { To discuss how to transition } \\
\text { from traditional consideration } \\
\text { versus utility in organ allocation } \\
\text { to a more subtle allocation } \\
\text { scheme based on ethical values } \\
\text { that drive decisions in times of } \\
\text { absolute scarcity. }\end{array}$ & $\begin{array}{l}\text { Test all donors. However, even with universal donor testing, } \\
\text { there will be false negatives. A negative test does not } \\
\text { guarantee zero risk of transmission from donors to recipients. } \\
\text { Evaluate the viability of the transplant before COVID-19, } \\
\text { question the structure, ethical values of decision-making, } \\
\text { risk-benefit ratio, immunosuppression. Can we recommend } \\
\text { that a dead donor take priority over a living individual who } \\
\text { needs ICU care and mechanical ventilation? }\end{array}$ \\
\hline $\begin{array}{l}\text { Donor organ } \\
\text { evaluation in the } \\
\text { era of coronavirus } \\
\text { disease } 2019: \text { A } \\
\text { case of nosocomial } \\
\text { infection }^{(26)}\end{array}$ & $\begin{array}{l}2020 \\
\text { USA }\end{array}$ & $\begin{array}{l}\text { Experience } \\
\text { report }\end{array}$ & $\begin{array}{l}\text { To report a case of hospital } \\
\text { infection during the } \\
\text { investigation for organ donation. }\end{array}$ & $\begin{array}{l}\text { Chest CT assists in the decision to accept the organ until the } \\
\text { PCR result is available. The RT-PCR multimodality test should } \\
\text { also be considered, as the virus may be present in areas of } \\
\text { the mucosa, such as in the intestine. Pay attention to cases } \\
\text { in which patients arrive asymptomatic and can acquire } \\
\text { COVID-19 upon admission. }\end{array}$ \\
\hline $\begin{array}{l}\text { Early impact of } \\
\text { COVID-19 on } \\
\text { transplant center } \\
\text { practices and } \\
\text { policies in the } \\
\text { United States }^{(27)}\end{array}$ & $\begin{array}{l}2020 \\
\text { USA }\end{array}$ & $\begin{array}{l}\text { Exploratory } \\
\text { study }\end{array}$ & $\begin{array}{l}\text { To understand the impact on } \\
\text { transplantation activity in the } \\
\text { United States and the variation } \\
\text { at the central level of testing, } \\
\text { clinical practice and policies. }\end{array}$ & $\begin{array}{l}\text { Test all low-risk donors for COVID-19 by PCR. All high-risk } \\
\text { donors test for PCR and BAL NAT. There is a nosocomial and } \\
\text { community spread in progress for potential deceased donors. }\end{array}$ \\
\hline $\begin{array}{l}\text { Classification of } \\
\text { the cutaneous } \\
\text { manifestations of } \\
\text { COVID-19: a rapid } \\
\text { prospective nation } \\
\text { wide consensus } \\
\text { study in Spain with } \\
375 \text { cases }^{(28)}\end{array}$ & $\begin{array}{l}2020 \\
\text { Spain }\end{array}$ & $\begin{array}{l}\text { Exploratory } \\
\text { study }\end{array}$ & $\begin{array}{l}\text { To describe the cutaneous } \\
\text { manifestations of COVID-19 } \\
\text { disease and relate it to other } \\
\text { clinical findings. }\end{array}$ & $\begin{array}{l}\text { Look out for vesicular lesions in middle-aged COVID-19 } \\
\text { patients. The presence of pruritus was very common in } \\
\text { urticarial and maculopapular lesions. An increase in the } \\
\text { number of herpes zoster cases has been noted. Pay attention } \\
\text { for any skin lesions that may arise. If an injury is identified, } \\
\text { further screening for COVID-19 is necessary. }\end{array}$ \\
\hline $\begin{array}{l}\text { Clinical } \\
\text { characteristics } \\
\text { of } 140 \text { patients } \\
\text { infected with SARS- } \\
\text { CoV-2 in Wuhan, } \\
\text { China } \\
\text { (29) }\end{array}$ & $\begin{array}{l}2020 \\
\text { China }\end{array}$ & $\begin{array}{l}\text { Exploratory } \\
\text { study }\end{array}$ & $\begin{array}{l}\text { To investigate clinical } \\
\text { characteristics and allergic status } \\
\text { of patients infected with SARS- } \\
\text { CoV-2. }\end{array}$ & $\begin{array}{l}\text { Observe signs of bilateral frosted glass or irregular opacity } \\
\text { in radiological findings. The presence of lymphopenia and } \\
\text { eosinopenia may be indicative of COVID-19. Loss of smell, } \\
\text { fever, fatigue and gastrointestinal symptoms may indicate } \\
\text { COVID-19. When one of these symptoms is noticed in patients, } \\
\text { a more prolonged and detailed investigation is necessary. }\end{array}$ \\
\hline $\begin{array}{l}\text { Clinical } \\
\text { characteristics of } \\
\text { novel coronavirus } \\
\text { cases in tertiary } \\
\text { hospitals in Hubei } \\
\text { Province }^{(30)}\end{array}$ & $\begin{array}{l}2020 \\
\text { China }\end{array}$ & $\begin{array}{l}\text { Exploratory } \\
\text { study }\end{array}$ & $\begin{array}{l}\text { To analyze the clinical } \\
\text { characteristics, treatment } \\
\text { regimens and prognosis of } \\
\text { patients infected with COVID-19. }\end{array}$ & $\begin{array}{l}\text { Pay attention to chest CT with lesions in multiple lung lobes. } \\
\text { Watch for fever, cough, pain or muscle fatigue, in addition to } \\
\text { lymphocytopenia. If these findings are identified, investigate } \\
\text { for COVID-19. }\end{array}$ \\
\hline $\begin{array}{l}\text { Clinical } \\
\text { Characteristics of } \\
\text { Coronavirus Disease } \\
2019 \text { in China } \\
\text { (31) }\end{array}$ & $\begin{array}{l}2020 \\
\text { China }\end{array}$ & $\begin{array}{l}\text { Exploratory } \\
\text { study }\end{array}$ & $\begin{array}{l}\text { To describe the results of } \\
\text { an analysis of the clinical } \\
\text { characteristics of COVID-19 in } \\
\text { a selected cohort of patients in } \\
\text { China. }\end{array}$ & $\begin{array}{l}\text { Observe chest CT: ground-glass opacity was the most } \\
\text { common radiological finding. Signs of lymphocytopenia, } \\
\text { fever at admission and during hospitalization and cough. }\end{array}$ \\
\hline
\end{tabular}

\section{DISCUSSION}

Most of the selected studies have as their main strategy to support the health team in the stages of the organ and tissue donation process, the performance of tests to detect SARS-CoV- 2 infection. This finding is in line with Technical Note $25 / 2020^{(8)}$ regarding the technical criteria for screening coronavirus in candidates for organ and tissue donation. According to the note, it is advised that the diagnosis of respiratory viruses, including SARS-CoV-2, be carried out via RT - PCR (Polymerase Chain Reaction - Reverse Transcription) in real time, following Charité protocol. The test detects viral RNA in samples collected in order of preference: nasopharyngeal aspirate, combined nasal and oral swab and sample of lower respiratory secretion (sputum, tracheal lavage or alveolar bronchus lavage $)^{(1,12,14-15,22-24,26-27,30)}$.
Considering the recommendations regarding the performance of the PCR exam before donation, it is important to note that there is a need and the imperiality of these exams to be collected by qualified professionals. This must be very careful when proceeding with the collection, due to the possibility of errors in the procedure, not obtaining sufficient material, contamination of the sample, among other factors that may occur. Professionals must follow the step by step regarding the recommendations of the health authorities to proceed with this collection ${ }^{(16)}$. Furthermore, it is important that the correct technique of collecting and storing collected samples is respected, which follow, in Brazil, the same guidelines for detecting the influenza virus. For the collection of nasopharyngeal aspirate, specific rules are used ${ }^{(14,22,24)}$.

One of the main recommendations before confirming organ and tissue donation is the need for the COVID-19 test to be negative. 
However, considering the current situation found in Brazil and in the world, in which most professionals are not qualified to work in the care of patients with COVID-19; still, given the scenario of contamination and death of these professionals ${ }^{(32-34)}$, the team's need to be cautious when proceeding with the collection of the PCR exam in potential organ and tissue donors. Two authors point out the need for the health team to have trained to work in any activities involving COVID-19 ${ }^{(12,15)}$. Allied to this situation, it is highlighted that, in some moments, there is a lack of kits for the development of these exams throughout the national territory ${ }^{(16-17)}$.

It is necessary to emphasize the possibility of false negative, of the immunological window, in addition to the team's unpreparedness to proceed with this collection. A study warns of the negative results of this exam, scoring the range of viral levels in COVID-19 and the ideal time to perform the collection of the material. Scholars point out that laboratory errors, precision of the test, co-infection and the oscillation of the viral load can interfere in the final result ${ }^{(35)}$. Any adverse event, error or incident in the collection of this exam may cause risk situations for several recipients. As for the recommendations for collecting this test, some researchers cite the need for it to be collected via the endotracheal route to increase the sensitivity of the test to the virus ${ }^{(7,22)}$.

Given the findings, the recommendation to the team that works in the donation process for collecting PCR is that it should be developed by a qualified professional, giving priority to the collection via endotracheal. It is important to highlight that, in case of suspected false negative examination, the recommendations follow for the investigation by means of chest CT. Two studies show that, even in patients who had a negative RT - PCR result, the radiological patterns obtained via chest $C T$ validated the diagnosis of COVID-19 ${ }^{(36-37)}$. Given this fact, it is pointed out that using chest $C T$ in potential donors of organs and tissues is an exam to be recommended and followed in order to ensure greater reliability of the final diagnosis for the absence of COVID-19 in donors. This recommendation is followed in donation centers in the Netherlands and the United States ${ }^{(22,26)}$. This recommendation is supported by the fact that approximately between $80 \%$ and $93 \%$ of patients diagnosed with COVID-19 presented chest CT with abnormal findings $s^{(1,29-31)}$.

To support the aforementioned recommendation regarding performing chest CT in potential donors, the São Paulo State Transplant Center has already contraindicated potential donors by identifying images suggestive of SARS-CoV2 infection, even with negative RT-PCR.

From the perspective of the investigation of potential donors by the team involved in the organ and tissue donation process, the findings of this study point to the need for a detailed investigation of signs and symptoms that can support this team in certifying that patients are not under suspicion of COVID-19. As mentioned in Chart 1, attention should be paid to the presentation of clinical symptoms, such as fever, dyspnea, dry cough, recent diarrhea, muscle pain or fatigue, lymphocytopenia(1,29-31), and some less common symptoms, such as sputum production and headache ${ }^{(1)}$.

Regarding the validation for an effective donor to proceed with organ removal, studies show divergences regarding absolute and relative contraindications, especially regarding the time to be waited, after the cure, for the donation to occur. This time varied between 21 and 28 days ${ }^{(7,23)}$. As for the absolute contraindication, there is a unanimous recommendation that the donation should be refused in potential asymptomatic donors, but who were in an affected area; clinical standard compatible with COVID-19; do not present compatible symptoms, but there is suspicion ${ }^{(7,14,23)}$.

Despite some divergences in relation to the days after patients' cure to become a potential donor, the other guidelines converge between the studies. The health team needs to carefully monitor every detail as to the history of possible contact of potential donors with affected areas, contaminated family members and other contacts, in addition to thorough and detailed physical examination, radiological and laboratory tests.

In Brazil, Technical Note 34/2020 is in accordance with such recommendations regarding absolute contraindications, which describes that potential donors with confirmation of COVID-19, or with a positive RT-PCR test for SARS-CoV-2, or patients with Severe Acute Respiratory Syndrome (SARS) without defined etiology and laboratory test not available are absolute contraindications for donation ${ }^{(11)}$. Regarding the time to be waited after cure for donation to occur, in Brazil, the time recommended by this same Technical Note is 28 days, supporting the study findings.

Faced with such care to be observed and evaluated to validate potential donors and continue with organ explant and transplantation, the articles bring strong recommendations regarding the development of transplants before the COVID-19 pandemic. Five of them point out the need for the transplant team to carefully evaluate a transplantation in times of pandemic ${ }^{(7,14-15,22,24)}$. The recommendations are to maintain transplants in case of urgency, always evaluating the cost benefit for patients' health, occupation of ICU beds, structure and situation of the team. Considering the COVID-19 pandemic scenario, studies carried out in China, Italy and France point out that, due to the effects of immunosuppressants, transplant patients are more likely to develop COVID-19 in its most severe form, with faster progression and worse prognosis ${ }^{(37-40)}$.

Recommendations for transplantation in urgent cases are enhanced by factors related to the team due to the possibility of contaminating potential donors during care at the critical patient unit; in addition to the team that will develop transplant being in contact with other patients and being able to contaminate recipients, as well as due to little training that health professionals received to care for patients undergoing transplantation before the COVID-19 pandemic ${ }^{(12,15,24,26)}$. One of the studies points out that, when developing care for a potential donor, all professionals must be qualified and prepared to deal with COVID-19 situations, both for diagnostic purposes and for the purpose of minimizing the risks of spreading this endemic disease ${ }^{(12)}$.

If it is considered the speed of spread of this virus, coupled with the number of contaminated health professionals who died from COVID-19 in Brazil and worldwide ${ }^{(32-34)}$, this recommendation is extremely relevant, given that there are still countless doubts about which precautions to prevent and control the spread of this disease. Certainly, care with potential donors and transplant recipients is innumerable for preventing the disease ${ }^{(41-42)}$. With the increase in demands for ICU beds for treatment of patients 
infected with the SARS-CoV-2 virus, cases of potential donors will be increasingly common with patients infected by the virus and, in this condition, the care team's care must be redoubled.

Another relevant point identified in the studies is the recommendation for testing of deceased donors ${ }^{(7,15)}$, which could facilitate the resumption of tissue uptake, especially the cornea of deceased donors, which are suspended at the SNT recommendation in its Technical Note 25/2020.

Finally, it is understood that, before the COVID-19 pandemic, the team working in the process of organ and tissue donation faces numerous challenges in validating potential donors in the decision to accept organs and in the criteria for transplantation. Therefore, it is necessary to be very cautious, tactful, responsible, committed, knowledgeable and ethical to understand that this is not the time to worry about the loss of potential organ and tissue donors, nor about reducing the number of transplants. It is a time of great serenity, resilience and team commitment to ensure that decision making to validate potential donors, as well as to accept organs, is based on criteria determined by national and international health organizations and the support of professionals with expertise in donation and transplantation, considering the recommendations for care before this pandemic.

Even so, it is extremely important that the Brazilian National Transplant System, National Transplant Center, State Transplant Centers and other entities involved in the organ and tissue donation process follow up, track and monitor possible adverse events that may arise in the pandemic scenario involving donation and transplantation issues. From this perspective, the biovigilance system must act in order to notify risks and adverse events to those involved in organ and tissue donation ${ }^{(43)}$.

It is believed that the recommendations evidenced in the study will subsidize nurses and health professionals working in organ donation and transplantation to determine the best interventions for potential donors, as well as more effective decision-making, given the resources available in the health system at this time of pandemic.

\section{Study limitations}

One of the limiting factors is the scarcity of studies regarding the reduction of the risk of contagion due to professional training to act amidst the COVID-19 pandemic. It is pointed out that, until the moment of the search, no randomized clinical studies were identified, in addition to the weaknesses of studies identified regarding the population sample. Some studies have been identified with a small population.

\section{Contributions to health}

Health professionals' decision-making in the process of organ and tissue donation needs support in the context of the COVID-19 pandemic. The present study brings international scientific evidence, as well as the recommendations of national organizations to support multidisciplinary team's decision-making before a potential donor, in addition to recommendations for carrying out transplants or not.

The scientific findings and the discussions presented can assist managers in resuming the activities of capturing tissue from donors deceased by PCR as well as resuming eye tissue transplants (cornea).

\section{FINAL CONSIDERATIONS}

The most recurrent recommendation in the selected studies was to test potential donors for SARS-CoV-2 infection. The preference for collection was aspirated from the nasopharynx, combined nasal and oral swab and, finally, a sample of lower respiratory secretion. Moreover, chest CT scan to have confidence in diagnosis.

The precautionary considerations for performing transplantations, as well as the judicious acceptance of potential donors, pointing out the recommendations based on clinical, laboratory and anamnesisrelated evidence, contribute to developing procedures and flows, which transplant teams can adopt to make these processes safer.

\section{REFERENCES}

1. Huang C, Wang Y, Li X, Ren L, Zhao J, Hu Y. Clinical features of patients infected with 2019 novel coronavirus in Wuhan, China. Lancet. 2020;39:507-497. https://doi.org/10.1016/S0140-6736(20)30183-5

2. Pan American Health Organization. Transmissão do SARS-CoV-2: implicações para as precauções de prevenção de infecção [Internet]. Brasília: Organização Pan-Americana da Saúde, 2020 [cited 2020 Nov 23]. Available from: https://iris.paho.org/bitstream/ handle/10665.2/52472/OPASWBRACOVID-1920089_por.pdf?sequence=1\&isAllowed=y

3. Ministério da Saúde (BR). Brasil confirma primeiro caso da doença[Internet]. 2020 [cited 2020 May 25]. Available from: https://www.saude. gov.br/noticias/agencia-saude/46435-brasil-confirma-primeiro-caso-de-novo-coronavirus

4. Ministério da Saúde (BR). Coronavírus Brasil[Internet]. 2020 [cited 2020 May 25]. Available from: https://covid.saude.gov.br/

5. Pan American Health Organization. OMS afirma que COVID-19 é agora caracterizada como pandemia [Internet]. 2020 [cited 2020 May 25]. Available from: https://www.paho.org/bra/index.php?option=comcontent \&view=article\&id=6120:oms-afirma-que-covid-19-e-agoracaracterizada-como-pandemia\&ltemid $=812$

6. Ministério da Saúde (BR). Portaria n 454, de 20 de março de 2020. Declara em todo território nacional, o estado de transmissão comunitária do coronavírus (covid-19). Diário Oficial da União. 20 março de 2020; Seção 1:1.

7. Moris D, Shaw BI, Dimitrokallis N, Barbas AS. Organ donation during the coronavirus pandemic: an evolving saga in uncharted waters. Transpl Int. 2020. https://doi.org/https://doi.org/10.1111/tri.13614

8. Ministério da Saúde (BR). Nota Técnica № 25/2020-CGSNT/DAET/SAES/MS: critérios técnicos para triagem clínica do coronavírus (SARS, MERS, SARS CoV-2) nos candidatos à doação de órgãos e tecidos para manejo do paciente em lista de espera e do transplantado. 2020. 
9. Presidência da República (BR). Decreto n 9.175, de 18 de outubro de 2017 - Regulamenta a Lei no 9.434, de 4 de fevereiro de 1997 , para tratar da disposição de órgãos, tecidos, células e partes do corpo humano para fins de transplante e tratamento. Diário Oficial da União. 19 outubro de 2017; Seção 1:3.

10. Associação Brasileira de Transplante de Órgãos-ABTO. Transplante e coronavírus[Internet]. 2020. [cited 2020 May 25]. Available from: http:// www.abto.org.br/abtov03/default.aspx?mn=487\&c=0\&s=156\&pop=true

11. Agência Nacional de Vigilância Sanitária. Nota Técnica № 34: Recomendações e alertas sobre procedimentos de desinfecção em locais públicos realizados durante a pandemia de COVID-19 [Internet]. 2020 [cited 2020 May 24]. Available from: http://portal.anvisa.gov.br/ documents/219201/4340788/SEl_ANVISA+-+0976782+-+Nota+T\% C3\%A9cnica.pdf/1cdd55e2f-fda1-4e55-aaa3-8de2d7bb447c

12. Pan L, Zeng J, Yang H. Challenges and countermeasures for organ donation during the SARS-CoV-2 epidemic: the experience of Sichuan Provincial People's Hospital. Intensive Care Med [Internet]. 2020. [cited 2020 May 22];46(5):844-5. Available from: https://pubmed.ncbi.nlm. nih.gov/32100062/

13. Ritschl PV, Nevermann N, Wiering L, Wu HH, Moroder P, Brandl A, et al. Solid organ transplantation programs facing lack of empiric evidence in the COVID-19 pandemic: a by-proxy society recommendation consensus approach. Am J Transplant [Internet]. 2020[cited 2020 May 22];00:12-1. Available from: https://onlinelibrary.wiley.com/doi/epdf/10.1111/ajt.15933

14. Angelico R, Trapani S, Manzia TM, Lombardini L, Tisone G, Cardillo M. The COVID-19 outbreak in Italy: Initial implications for organ transplantation programs. Am J Transplant [Internet]. 2020[cited 2020 May 22]:5-1. Available from: https://onlinelibrary.wiley.com/doi/full/10.1111/ajt.15904

15. Kumar D, Manuel O, Natori Y, Egawa H, Grossi P, Han SH, et al. COVID-19: a global transplant perspective on successfully navigating a pandemic. Am J Transplant [Internet]. 2020[cited 2020 May 22];00:7-1. Available from: https://www.ncbi.nlm.nih.gov/pmc/articles/ PMC72283 01/pdf/AJT-9999-na.pdf

16. Vieira LMF, Emery E, Andriolo A. Covid-19: laboratory diagnosis for clinicians. Health Sci. 2020. Scielo Preprints [cited 2020 May 28]. https:// doi.org/10.1590/SciELOPreprints.411

17. Braz MV. A pandemia de covid-19 (SARS-CoV-2) e as contraindicações do mundo do trabalho. Rev Laborativa [Internet]. 2020[cited 2020 May 25];9(1):130-16. Available from: https://ojs.unesp.br/index.php/rlaborativa/article/vi ew/3192/pdf

18. Wang Y, Liu H, Buhler LH, Deng S. Strategies to halt 2019 novel coronavirus (COVID-19) spread for organ transplantation programs at the Sichuan Academy of Medical Science and Sichuan Provincial People's Hospital, China. Am J Transplant [Internet]. 2020 [cited 2020 May 22]. Available from: https://onlinelibrary.wiley.com/doi/epdf/10.1111/ajt.15972

19. Woolley AE, Mehra MR. Dilemma of organ donation in transplantation and the COVID-19 pandemic. J Heart Lung Transpl [Internet]. 2020 [cited 2020 May 22];39(5):410-1. Available from: https://www.jhltonline.org/article/S1053-2498(20)31478-9/pdf

20. Peters MDJ, Godfrey C, McInerney P, Munn Z, Tricco AC, Khalil H. Chapter 11: scoping reviews (2020 version). In: Aromataris E, Munn Z (Eds.). JBI Manual for Evidence Synthesis. 2020. https://doi.org/10.46658/JBIMES-20-12

21. Tricco AC, Lillie E, Zarin W, O'Brien KK, Colquhoun H, Levac D, et al. PRISMA extension for scoping reviews (PRISMA-ScR): checklist and explanation. Ann Intern Med. 2018,169(7):467-73. https://doi.org/10.7326/M18-0850

22. Vries APJ, Alwayn IPJ, Hoek RAS, Berg APVD, Ultee FCW, Vogelaar SM, et al. Immediate impact of COVID-19 on transplant activity in the Netherlands. Transp Immunol. 2020;7-1. https://doi.org/10.1016/j.trim.2020.101304

23. Domínguez-Gil B, Coll E, Ferrer-Fàbrega, Briceño J, Ríos A. Dramatic impact of the COVID-19 outbreak on donation and transplantation activities in Spain. Cir Espan. 2020;6-1. https://doi.org/ 10.1016/j.ciresp.2020.04.012

24. Gori A, Dondossola D, Anttonelli B, Mangioni D, Alagna L, Reggiani P, et al. Coronavirus disease 2019 and transplantation: a view from the inside. Am J Transpl. 2020:2-1. https://doi.org/10.1111/ajt.15853

25. Wall AE, Pruett T, Stock P, Testa G. Coronavirus disease 2019: utilizing an ethical framework for rationing absolutely scarce health-care resources in transplant allocation decisions. Am J Transpl. 2020;00:5-1. https://doi.org/10.1111/ajt.15914

26. Krishan J, Tina RNK, Dael G, Lawrence C, Fardad E, Jon AK, Jignesh K. Donor organ evaluation in the era of coronavirus disease 2019: a case of nosocomial infection. J Heart Lung Transpl. 2020. https://doi.org/10.1016/j.healun.2020.04.005

27. Boyarsky BJ, Po-Yu Chiang T, Werbel WA, Durand CM, Avery RK, Getsin SN, et al. Early impact of COVID-19 on transplant center practices and policies in the United States. Am J Transplant. 2020:10-1. https://doi.org/10.1111/ajt.15915

28. Casas CG, Catalá A, Hernández GC, Rodríguez-Jiménez P, Nieto DF, Lario ARV. Classification of the cutaneous manifestations of COVID-19: a rapid prospective nationwide consensus study in Spain with 375 cases. Br J Dermatol. 2020. https://doi.org/10.1111/bjd.19163

29. Zhang JJ, Dong X, Cao YY, Yang YB, Yan YG, Akdis CA et al. Clinical characteristics of 140 patients infected with SARS-CoV-2 in Wuhan, China. Allergy. 2020:12-1. https://doi.org/10.1111/all.14238

30. Kui L, Yuan-Yuan F, Yan D, Wei L, Mei-Fang W, Jing-Ping M, et al. Clinical characteristics of novel coronavirus cases in tertiary hospitals in Hubei Province. Chin Med J. 2020;133(9):1031-25. https://doi.org/10.1097/CM9.0000000000000744

31. Guan WJ, Ni, ZY, Hu Y, Liang WH, Ou CQ, He JX et al. Clinical characteristics of Coronavirus Disease 2019 in China. N Engl J Med. 2020;382:1720-08. https://doi.org/10.1056/NEJMoa2002032

32. Oliveira C. Quase 70\% dos profissionais da saúde não receberam treinamento para covid-19 no país [Internet]. 2020 [cited 2020 May 22 ]. Available from: https://www.brasildefato.com.br/2020/04/16/quase-70-dos-profissionais-da-saude-nao-receberam-treinamento-para-covid-19-no-pais 
33. Conselho Federal de Enfermagem. Brasil tem 108 enfermeiros mortos e mais 4,1 mil contaminados pelo coronavírus [Internet]. 2020 [cited 2020 May 22]. Available from: http://www.cofen.gov.br/brasil-tem-108-enfermeiros-mortos-e-mais-de-41-mil-contaminados-pelocoronavirus_79784.html

34. Miranda FMA, Santana LL, Pizzolato AC, Saquis LMM. Working conditions and the impact on the health of the nursing professionals in the context of covid-19. Cogitare Enferm. 2020;25. https://doi.org/10.5380/ce.v25i0.72702

35. Oliveira ES, Matos MF, Morais ACLN. Perspectiva de resultados falso-negativos no teste de RT-PCR quando realizado tardiamente para o diagnóstico de covid-19. InterAm J Med Health. 2020;3. https://doi.org/10.31005/iajmh.v3i0.90

36. Xie X, Zhong Z, Zhao W, Zheng C, Wang F, Liu J. Chest CT for typical 2019-nCoV pneumonia: relationship to negative RT-PCR Testing. Radiol. 2020. https://doi.org/10.1148/radiol.2020200343

37. Liu H, He X, Wang Y, Zhou S, Zhang D, Zhu J, et al. Management of COVID-19 in patients after liver transplantation: Beijing working party for liver transplantation. Hepatol Int. 2020. https://doi.org/10.1007/s12072-020-10043-z

38. Zhu L, Xu X, Ma K, Yang J, Guan H, Chen S, et al. Successful recovery of COVID-19 pneumonia in a renal transplant recipient with long-term immunosuppression. Am J Transplant. 2020;00:5-1. https://doi.org/10.1111/ajt.15869

39. Fishman JA, Grossi PA. Novel Coronavirus-19 (COVID-19) in the immune compromised transplant recipient: \#Flatteningthecurve. Am J Transpl. 2020:3-1. https://doi.org/0.1111/ajt.15890

40. Tzedakis S, Jeddou H, Houssel-Debry P, Sulpice L, Boudjema K. COVID-19: Thoughts and comments from a tertiary liver transplant center in France. Am J Transpl. 2020:2-1. https://doi.org/10.1111/ajt.15918

41. Martin R, Sierra-Ruiz M, Barrera-Lozano LM. Organ donation and transplantation in the COVID-19 era: should programs really stop?. Rev Colomb Cir. 2020;35(2):227-34. https://doi.org/10.30944/20117582.624

42. Suárez MMÁ, Santoyo SJ. Implicaciones de la infección por COVID-19 en el trasplante de órganos. Cir Andal [Internet]. 2020 [cited 2020 May 28];31(2):164-66. Available from: https://www.asacirujanos.com/admin/upfiles/revista/2020/Cir_Andal_vol31_n2_18.pdf

43. Treviso P, Amorim MHC, Schirmer J, Roza BA. Biosurveillance: quality and safety in the process of organ and tissue donation and transplantation. Rev SOBECC. 2020;25(1):2-1. https://doi.org/10.5327/Z1414-4425202000010001 